\title{
Article \\ Effect of Biochar Application Depth on a Former Mine Technosol: Impact on Metal(Loid)s and Alnus Growth
}

\author{
Gloria Palmeggiani ${ }^{1}$, Manhattan Lebrun ${ }^{1}$, Melissa Simiele ${ }^{1,2}$, Sylvain Bourgerie ${ }^{1}$ and Domenico Morabito ${ }^{1, *}$ (I) \\ 1 INRA USC1328, LBLGC EA1207, Rue de Chartres, University of Orleans, BP 6759, CEDEX 2, \\ 45067 Orléans, France; palmeggiani.1856563@studenti.uniroma1.it (G.P.); manhattan.lebrun@inrae.fr (M.L.); \\ melissa.simiele@studenti.unimol.it (M.S.); sylvain.bourgerie@univ-orleans.fr (S.B.) \\ 2 Dipartimento di Bioscienze e Territorio, Università degli Studi del Molise, 86090 Pesche, Italy \\ * Correspondence: domenico.morabito@univ-orleans.fr
}

Citation: Palmeggiani, G.; Lebrun,

M.; Simiele, M.; Bourgerie, S.;

Morabito, D. Effect of Biochar

Application Depth on a Former Mine

Technosol: Impact on Metal(Loid)s and Alnus Growth. Environments 2021, 8, 120. https://doi.org/10.3390/

environments 8110120

Academic Editor: Paula Alvarenga

Received: 14 September 2021

Accepted: 25 October 2021

Published: 3 November 2021

Publisher's Note: MDPI stays neutral with regard to jurisdictional claims in published maps and institutional affiliations.

Copyright: (c) 2021 by the authors. Licensee MDPI, Basel, Switzerland. This article is an open access article distributed under the terms and conditions of the Creative Commons Attribution (CC BY) license (https:/ / creativecommons.org/licenses/by/ $4.0 /)$.

\begin{abstract}
The contamination of soil by potentially toxic elements (PTEs) is a problem resulting from various anthropic activities including the exploitation of mines, which determines an accumulation of metal(loid)s in the surrounding area. It is therefore necessary to use remediation techniques to prevent the potential damage to human health and the ecosystem. One of these techniques is phytoremediation, which involves the revegetation of contaminated areas in such a way as to reduce the spread of contaminants and entry into the groundwater by stabilizing the metal(loid)s in the soil, decreasing their mobility. To increase the ability of plants to grow under the extreme conditions of contaminated soils, it is necessary to use amendments, which can also intervene directly in reducing the mobility of contaminants. In this study, an open-field mesocosm was set up using a former mining technosol contaminated mainly by As. A biochar produced from hardwood was added at two different depths to evaluate the effectiveness of these application modalities for an overall observation duration of 17 months. Iron sulphate was also applied in both non-biochar and biochar amended conditions. In addition, trees of Alnus sp. were planted to examine the effectiveness of these plants for their use in soil remediation and the effect of the treatments used. The results showed an increase in soil $\mathrm{pH}$ induced by the biochar, which decreased over time. During the period examined, the application of biochar in the deepest layer was able to retain As more effectively. The Alnus sp. showed similar growth rates among the various treatments, resulting from its tolerance towards arsenic.
\end{abstract}

Keywords: alder; phytoremediation; soil restoration; arsenic

\section{Introduction}

Soil contamination by pollutants is one of the major problems of our modern society, which is correlated with industrial development. This pollution is responsible for the alteration of biogeochemical cycles, causing the degradation of ecosystems and risks to human health through multiple exposure routes such as entry into the food chain. The European Environment Agency [1] reported that over 300,000 contaminated sites have already been identified in Western Europe, and across Europe the overall estimated number is even higher. The main activities that cause soil contamination are related to human activities and urbanization such as the use of pesticides for agricultural purposes, the oil industry, incorrect waste disposal, the combustion processes, the use of solvents and the extraction and refining of metals and metalloids [2,3]. These activities can deteriorate the soil and cause irreversible damage.

Metal(loid)s are a major cause of environmental contamination and are mainly related to human activities such as mining, which has existed for many years and is still growing [4]. During mining activities, extraction residues are produced and deposited on site. These residues contain large quantities of potentially toxic elements (PTEs) including heavy metals (HM) such as $\mathrm{Zn}, \mathrm{Ni}, \mathrm{Pb}$ and $\mathrm{Cu}$ and metalloids such as As, which, due to leaching, 
diffusion and infiltration, are transported to the surface and/or ground water, resulting sometimes in acid drainage [5]. Heavy metals and many metalloids are toxic and can have negative effects, even at very low concentrations, such as the induction of oxidative stress through the production of free radicals. When dispersed in the environment, they can lead to a lack of soil capacity to host vegetation [6] by altering the chemico-physical properties of the soil and the soil pore water. Arsenic is one of the most dangerous metalloids for human health [7]. It can leach into groundwater, contaminating drinking water, and damaging the digestive and the cardio-respiratory systems. Thus, according to European Union legislation, total As concentration in drinking water must not exceed $10 \mu \mathrm{g} \mathrm{L}^{-1}$ [8].

Various methods have been developed for the reduction of metal(loid) risks towards the environment and human health, through the removal or the stabilization of metal(loid)s. For this, different chemical and physical techniques have been developed, such as mechanical and pyrometallurgical separation, soil flushing, and soil washing [9]. However, a more sustainable and cost-effective technique has attracted attention over recent decades: phytoremediation $[4,10]$. Phytoremediation is an eco-friendly, green-based solution, which uses plants, associated or not with amendments, to reduce the risks induced by the pollution present in a soil. It includes a series of techniques, which can be used and selected according to the type of contamination and the nature of the contaminant, the characteristics of the site to be treated and the plant species used. One of the possibilities is the use of amendments to reduce the mobility and bioavailability of metals (stabilization) in a soil, to improve its agronomic qualities in order to allow the growth of plants that will limit the dispersion of pollutants by the wind or by leaching to the neighboring environmental compartments [11]. This technique, called assisted-phytostabilization, will allow, on a soil unsuitable for the plant development, the installation of a vegetation cover during successive growth seasons and the restoration of an ecosystem in which the pollution is sequestered. It will also have a positive aesthetic impact [12]. This technique is proposed for large areas of pollution where it is impossible to consider a physical and/or chemical technique that would be too expensive and disruptive to the soil.

In most contaminated soils, such as those of former mines, there are problematic conditions for the establishment of vegetation, especially the extreme $\mathrm{pH}$ and the low content of nutrients [13] and, therefore, the use of amendments is required to allow for plant growth [14,15]. An amendment that has shown excellent capabilities in this regard is biochar. It is an organic porous compound obtained mainly from the pyrolysis of vegetal biomass produced from agricultural and forest waste, manure or mineral sources, that can be used as soil improver. Biochar appears as a structured carbon matrix with a high surface/mass ratio, which allows it to absorb certain charged elements on its surface [16]. Adding biochar to soil improves the overall soil health and quality, root growth, soil biodiversity, and helps in the immobilization of contaminants. It allows a better water retention capacity, a $\mathrm{pH}$ increase, and long-term carbon sequestration. This finally permits the implementation and growth of plants [17]. The increase in $\mathrm{pH}$ and the biochar negative charges can cause a decrease in the bioavailability of positively charged ions like Pb but it has been shown to have no effect or to mobilize negatively charged anions like As [18]. To immobilize As in the presence of biochar, an Fe-based compound, such as iron sulphate, can be used due to the high affinity between As and Fe, and thus As mobility is reduced through adsorption or surface precipitation [19,20]. Mahmood-ul-Hassan et al. [21] proved that the As concentration of brown rice grain is considerably decreased when soils were amended with iron sulphate, which masks the impact of As toxicity on its growth and uptake. Thus, the possibility of combining biochar and iron sulphate on multi contaminated soil (with both anions and cations) could be an interesting solution. Indeed, Fe-containing chemicals are selected because Fe-(hydr)oxides display a high affinity for oxyanions such as arsenate [22]. Thus, in order to allow the stabilization of arsenic and prevent its mobility, iron sulfate could be added to polluted soils at the same time as biochar. It is proposed that the iron will associate with the biochar, which reduces the risk of iron loss by leaching and moreover it has been shown that once fixed on the biochar, the iron allows the fixation of 
arsenic by adsorption and precipitation processes [23-25]. Finally, it has been shown that the application of Fe-enriched adsorbents can alter the chemical and physical properties of soils and reduce the As chemo-availability [26].

Among the different plants proposed for phytoremediation, the Alnus tree genus could be used as it is a pioneer plant presenting rapid growth that is capable of adapting to soils with a low amount of nutrients. Moreover, through root symbiosis with bacteria, it can improve its assimilation of atmospheric nitrogen [27] and is able to produce an expanded root system [28].

The aim of this study was to evaluate the potential of a biochar + iron sulphate amendment associated with Alnus plant establishment for the phytostabilization of a former tin mine located in Abbaretz (Pays-de-la-Loire, France), highly contaminated with As. In more detail, the objectives were (i) to evaluate the biochar + iron sulphate effect and biochar depth incorporation effect on the physico-chemical properties of the soil pore water sampled at two depths; (ii) to assess Alnus' effect on the soil pore water; (iii) to observe the changes over time in the soil pore water's physico-chemical properties and concentration of As and Fe; and (iv) to determine the stem plant biomass and its concentration in As and Fe.

\section{Material and Methods}

\subsection{Site of Study}

The contaminated soil used for the present study was a post-mining soil situated at Abbaretz, $\left(47^{\circ} 33^{\prime} 42^{\prime \prime}\right.$ North, $1^{\circ} 32^{\prime} 38^{\prime \prime}$ West). The extractive activities were carried in the Gallo-Romanesque period and then during the twentieth century, to extract tin (Sn) mineral (Gloaguen et al. 2018). The ore mined consists mainly of cassiterite (tin oxide, $\mathrm{SnO}_{2}$ ) in the first few meters, while sulphides appear more frequently at the deepest levels, always in the form of arsenopyrite. The average soil As concentration measured by the French National Geological Service (BRGM) in 2009 corresponds to $291 \mathrm{mg} \mathrm{kg}^{-1}$. Due to As pollution, access to the mine is currently restricted. In addition to the high As soil pollution, acid mine drainage is present on this site: sulphide mineral residuals contaminated in the heaps, in contact with atmospheric air and (rain) water, oxidize and dissolve, generating acidic water ( $\mathrm{pH}=3$ to 4$)$ loaded with trace elements, dissolved metals, and sulphates. The Abbaretz technosol chemico-physical proprieties were obtained from [20] (Table 1).

Table 1. Physico-chemical properties of the soil and the amendments.

\begin{tabular}{llll}
\hline & Abbaretz Technosol & Iron Sulphate ** \\
\hline $\mathrm{pH}$ & $5.15 \pm 0.04$ & Biochar $^{* *}$ & $2.6 \pm 00$ \\
Electrical conductivity $\left(\mu \mathrm{S} \cdot \mathrm{cm}^{-1}\right)$ & $16 \pm 0.3$ & $8.46 \pm 0.01$ & $\mathrm{Nd}$ \\
Water holding capacity $(\%)$ & $35 \pm 0.1$ & $302 \pm 1$ & $\mathrm{Nd}$ \\
Cation exchange capacity $\left(\mathrm{cmol}(+) \cdot \mathrm{kg}^{-1}\right)$ & $\mathrm{Nd}$ & $212 \pm 4$ & $\mathrm{Nd}$ \\
Specific surface area $\left(\mathrm{m}^{2} \cdot \mathrm{g}^{-1}\right)$ & $\mathrm{Nd}$ & $<1.05$ & $\mathrm{Nd}$ \\
Total pore volume $\left(\mathrm{cm}^{3} \cdot \mathrm{g}^{-1}\right)$ & $\mathrm{Nd}$ & 4.38 & $\mathrm{Nd}$ \\
Mean pore diameter $(\mathrm{nm})$ & $\mathrm{Nd}$ & 0.01 & $\mathrm{Nd}$ \\
$\mathrm{C}(\%)$ & $\mathrm{Nd}$ & 9.13 & $\mathrm{Nd}$ \\
$\mathrm{H}(\%)$ & $\mathrm{Nd}$ & $79 \pm 1$ & $\mathrm{Nd}$ \\
$\mathrm{N}(\%)$ & $\mathrm{Nd}$ & $1.74 \pm 0.07$ & $\mathrm{Nd}$ \\
Total [As] $(\mathrm{mg} \cdot \mathrm{kg}-1)$ & $297 \pm 30$ & $2.4 \pm 0.8$ & $\mathrm{Nd}$ \\
Phytoavailable $[\mathrm{As}]\left(\mathrm{mg} \cdot \mathrm{kg}^{-1}\right)$ & $3.3 \pm 0.7$ & $\mathrm{Nd}$ & $16.5 \pm 0.5$ \\
Phytoavailable $[\mathrm{Fe}]\left(\mathrm{mg}^{-1} \mathrm{~kg}^{-1}\right)$ & $9.3 \pm 0.9$ & $0.9 \pm 0.1$ & $23265 \pm 299$ \\
Phytoavailable $[\mathrm{P}]\left(\mathrm{mg}_{\mathrm{kg}}^{-1}\right)$ & $9.7 \pm 1.7$ & $8 \pm 5$ & $25.4 \pm 1.2$ \\
Phytoavailable $[\mathrm{K}]\left(\mathrm{mg} \cdot \mathrm{kg}^{-1}\right)$ & $\mathrm{Nd}$ & $752 \pm 30$ & $7.9 \pm 0.7$ \\
\hline
\end{tabular}

* data from Simiele et al. [20]; ** data from Lebrun et al. [29] and Nandillon et al. [15]. 


\subsection{Biochar and Iron Sulphate}

As reported by Simiele et al. [20], the biochar used was provided by La Carbonerie (Crissey, France) and derives from the slow pyrolysis (temperature of $500{ }^{\circ} \mathrm{C}$ with a heating rate of $2.5^{\circ} \mathrm{C} \cdot \mathrm{min}^{-1}$ and a $3 \mathrm{~h}$ residence time) of oak, beech and charm wafers and chips. The pyrolysed material was crushed to obtain a final granulometry between $0.5-1 \mathrm{~mm}$. The iron sulphate used was a commercial product START ${ }^{\circledR}$ from Star-Jardin (Nouâtre, France). The chemico-physical characterization of these materials as calculated in previous studies are shown in Table $1[15,29]$.

\subsection{Alnus}

The alder plants used (Alnus sp.) were obtained from seedlings produced from seeds collected on a tree in a contaminated area located in Pontgibaud (Puy-de-Dôme, France) (Lambert II coordinates: X: 637,898.27 and Y: 2,087,992.92). Plants were grown for two years on a regular soil (compost $1 / 2$ and garden soil $1 / 2$ ) before they were transferred to the tested soils. The selected plants were of similar size and had comparable root systems. At the beginning of the experiment, the aerial parts of the plants were pruned at $10 \mathrm{~cm}$ from the ground.

\subsection{Mesocosms Settlement}

The present experiment was the continuation of the work undertaken by Simiele et al. [20]. It consisted of a mesocosm open-field settlement started in April 2017 at the National Forestry Office in Guéméné-Penfao (France). The experiment took place within $10 \mathrm{~km}$ of the polluted area so that the climatic and altimetric conditions were as close as possible to those observed on the site from which the polluted soils originated. Three conditions were set up in PVC tubes $(100 \mathrm{~cm}$ height, $30 \mathrm{~cm}$ diameter). The first tested condition consisted of the contaminated soil collected from the mine (Abbaretz soil alone, $\mathrm{AB})$, the second corresponded to $\mathrm{AB}$ soil mixed with $2 \%$ biochar on the $1 / 3$ upper part of the cylinders $(A B+1 / 3 B C)$, the third tested condition corresponded to the cylinders filled with $A B$ soil mixed with $2 \%$ biochar on the entire length (AB + BC). On March 2018, $25 \mathrm{~g}$ of iron sulphate was added on the top of each tube. After 1 year of soil maturation, one alder tree was planted per cylinder (seven replicates per treatment). For each of the three treatments, one batch of tubes was left without vegetation (seven replicates per treatment). The water supply was provided by rain and, if necessary, the soils were watered with groundwater. A representation of the experimental design is given Figure 1a.

\subsection{Soil pore Water (SPW) and Plant Organs Analysis}

SPW was collected using Rhizons ${ }^{\circledR}$ (model MOM, Rhizosphere Research Products, Wageningen, The Netherlands) samplers placed at two depths, i.e., upper level $(17 \mathrm{~cm}$ from above) and lower level ( $83 \mathrm{~cm}$ from above). The sampling at two depths was performed in order to evaluate the leaching potential of metal(loid)s and thus the possible composition of acid mine drainage. For each SPW sample, $\mathrm{pH}$ and electrical conductivity (EC) were measured (multimeter, Mettler-Toledo, Seven Excellence) and $5 \mathrm{~mL}$ of subsample were taken, acidified with $83 \mu \mathrm{L}$ of $65 \% \mathrm{HNO}_{3}$ and stored at $4{ }^{\circ} \mathrm{C}$ before As and Fe quantification (Inductively Coupled Plasma Atomic Emission Spectroscopy (ICP-AES), ULTIMA 2, HORIBA, Labcompare, San Francisco, CA, USA). The first set of SPW was collected in October 2019 (T7) and the second in October 2020 (T19). The monitoring of SPW is summarized in Figure 1b. 


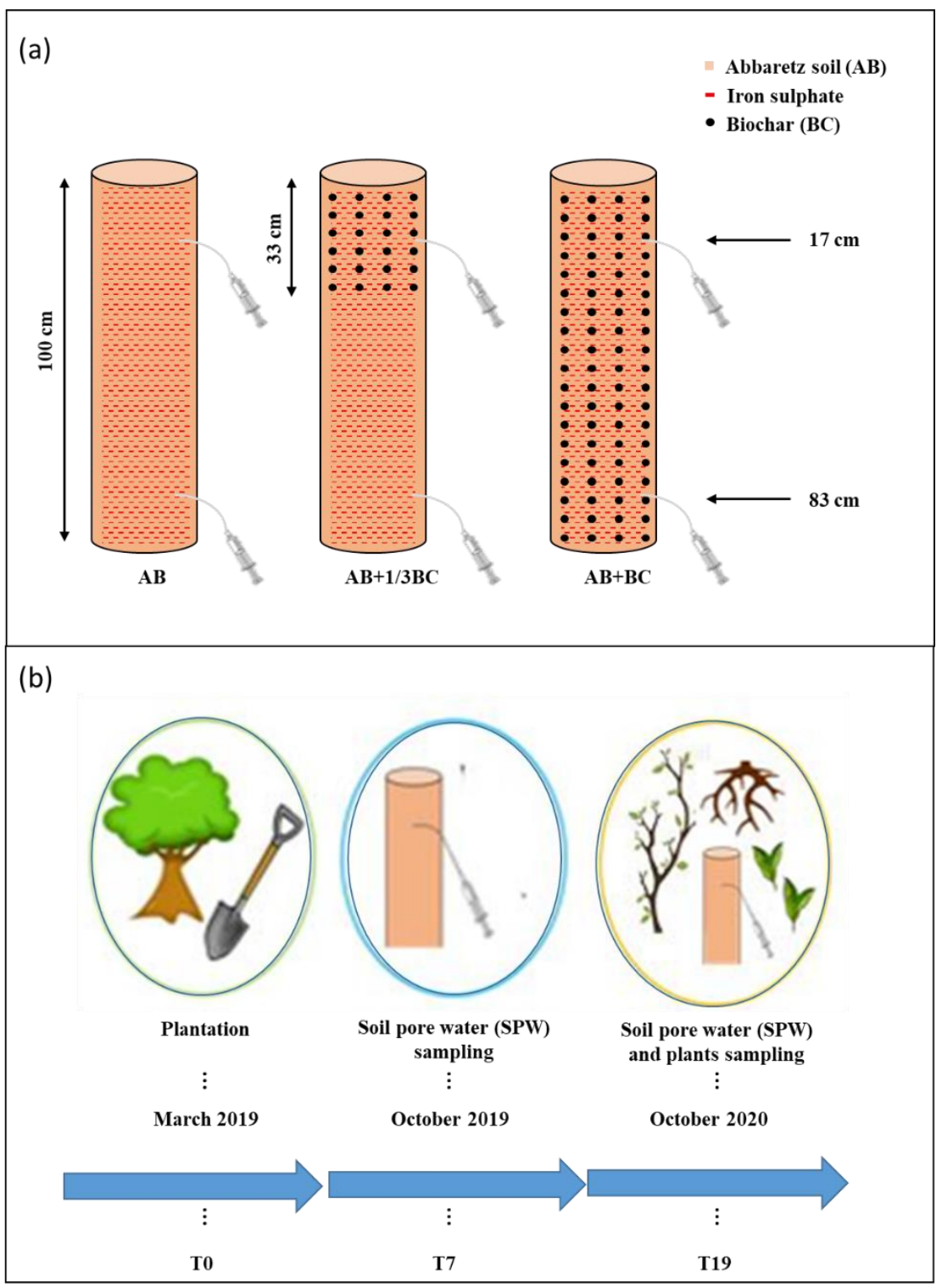

Figure 1. Representation of the experimental design (a) and monitoring (b) (adapted from [20]).

Plant organs were collected at T19 and were washed twice with tap water and once with distilled water (Figure 1b). Subsequently, the roots, stems and leaves were separated and dried at $50{ }^{\circ} \mathrm{C}$ for two days. The dried material was weighed for biomass determination and the different organs were crushed before mineralization. The mineralization procedure was obtained using $200 \mathrm{mg}$ of plant material mixed with $3 \mathrm{~mL}$ of $\mathrm{HCl}(37 \%)$ and $6 \mathrm{~mL}$ of $\mathrm{HNO}_{3}(65 \%)$ in a teflon tube. The tubes were then placed in a microwave (Multiwave 5000, Anton Paar, Courtaboeuf, France), the mineralization conditions were as follows: increase in temperature for $15 \mathrm{~min}$ to reach $160^{\circ} \mathrm{C}$, hold temperature for $30 \mathrm{~min}$ at $160{ }^{\circ} \mathrm{C}$, and cool to room temperature for $30 \mathrm{~min}$. The digested samples were then recovered and diluted with distilled water up to $50 \mathrm{~mL}$. Finally, the solutions were filtered under vacuum with cellulose nitrate filter $(0.45 \mu \mathrm{m})$. The As and Fe content was measured using ICP-AES.

\subsection{Statistical Analysis}

All statistical analyses were carried out using R (3.6.1) software (Vienna, Austria) [30]. In all cases, the Shapiro test was used to verify the normality of the data, then the Bartlett (if $p$-value was $>0.05$ ) or Fligner (if $p$-value $\leq 0.05$ ) tests were applied to verify the homogeneity of variance. Following this, the means of the three treatments $(A B, A B+1 / 3 B C$, 
and $\mathrm{AB}+\mathrm{BC}$ ) were compared for the vegetated and unvegetated conditions separately using the ANOVA (for parametric data) or Kruskal-Wallis (for non-parametric data) tests, followed by a post hoc test, i.e., Tukey HSD or pairwise Wilcox tests, respectively. Moreover, vegetation, time and level effects were evaluated for the soil pore water data. For this, the same procedure as described previously was used, except means were compared using the Student test (if $p$-value $>0.05$ ) or the Wilcox test (if $p$-value $\leq 0.05$ ). Difference was considered significant at $p<0.05$.

\section{Results and Discussion}

\subsection{SPW Chemico-Physical Properties}

At $\mathrm{T} 7$, the $\mathrm{pH}$ of the control treatment $\mathrm{AB}$ was the most acidic, with values averaging from 6.1 to 6.5 for the unvegetated and vegetated condition, respectively, at the up level and 5.7 and 5.9 at the down level (Table 2).

Table 2. Soil pore water (SPW) chemico-physical properties ( $\mathrm{pH}$ and electrical conductivity) determined on $\mathrm{Abbaretz}(\mathrm{AB})$ technosol non-amended or amended with $2 \%$ biochar added for the top $33 \mathrm{~cm}$ of the tube $(\mathrm{AB}+1 / 3 \mathrm{BC})$ or for the entire tube $(A B+B C)$ in the unvegetated tubes and in the tubes vegetated with Alnus sp. SPW was sampled both at the top (17 $\mathrm{cm}$ ) and at the bottom $(83 \mathrm{~cm})$ of the tubes in October 2019 (T7) and in October 2020 (T19).

\begin{tabular}{|c|c|c|c|c|c|c|c|c|c|}
\hline & \multicolumn{3}{|c|}{ Top } & \multicolumn{3}{|c|}{ Bottom } & \multicolumn{3}{|c|}{ Level Effect } \\
\hline & $\mathbf{A B}$ & $A B+1 / 3 B C$ & $A B+B C$ & $\mathrm{AB}$ & $A B+1 / 3 B C$ & $A B+B C$ & AB & $A B+1 / 3 B C$ & $A B+B C$ \\
\hline \multicolumn{10}{|l|}{ pH-T7 } \\
\hline Unvegetated & $6.1 \pm 0.2 b, A$ & $7.1 \pm 0.2 \mathrm{a}, \mathrm{A}$ & $7.0 \pm 0.4 \mathrm{ab}, \mathrm{A}$ & $5.7 \pm 0.4 b, \mathrm{~A}$ & $7.1 \pm 0.2 \mathrm{a}, \mathrm{A}$ & $7.0 \pm 0.1 \mathrm{a}, \mathrm{A}$ & ns & ns & ns \\
\hline Vegetated & $6.5 \pm 0.1 \mathrm{~b}, \mathrm{~A}$ & $6.9 \pm 0.1 \mathrm{a}, \mathrm{A}$ & $6.8 \pm 0.1 \mathrm{ab}, \mathrm{A}$ & $5.9 \pm 0.1 \mathrm{~b}, \mathrm{~A}$ & $6.8 \pm 0.1 \mathrm{a}, \mathrm{A}$ & $7.0 \pm 0.1 \mathrm{a}, \mathrm{A}$ & $* *$ & ns & ns \\
\hline \multicolumn{10}{|l|}{ pH-T19 } \\
\hline Unvegetated & $6.0 \pm 0.1 b, A$ & $6.4 \pm 0.1 \mathrm{a}, \mathrm{A}$ & $6.7 \pm 0.1 \mathrm{a}, \mathrm{A}$ & $5.8 \pm 0.1 \mathrm{c}, \mathrm{A}$ & $6.3 \pm 0.1 \mathrm{~b}, \mathrm{~A}$ & $6.9 \pm 0.1 \mathrm{a}, \mathrm{A}$ & ns & ns & ns \\
\hline Vegetated & $6.1 \pm 0.1 \mathrm{a}, \mathrm{A}$ & $6.1 \pm 0.1 \mathrm{a}, \mathrm{B}$ & $6.3 \pm 0.1 \mathrm{a}, \mathrm{B}$ & $6.0 \pm 0.1 \mathrm{~b}, \mathrm{~A}$ & $6.2 \pm 0.1 \mathrm{~b}, \mathrm{~A}$ & $6.7 \pm 0.1 \mathrm{a}, \mathrm{A}$ & ns & ns & ns \\
\hline \multicolumn{10}{|l|}{$\begin{array}{c}\text { pH-Time } \\
\text { effect }\end{array}$} \\
\hline Unvegetated & ns & $*$ & ns & ns & $* *$ & ns & & & \\
\hline Vegetated & ns & $* * *$ & $*$ & ns & $* * *$ & $*$ & & & \\
\hline \multicolumn{10}{|l|}{ EC-T7 } \\
\hline Unvegetated & $213 \pm 46 a, B$ & $340 \pm 88 \mathrm{a}, \mathrm{A}$ & $343 \pm 100 a, A$ & $333 \pm 56 a, A$ & $417 \pm 119 a, A$ & $360 \pm 162 a, A$ & ns & ns & ns \\
\hline Vegetated & $453 \pm 47 \mathrm{a}, \mathrm{A}$ & $489 \pm 53 a, A$ & $681 \pm 186 a, A$ & $466 \pm 68 b, A$ & $564 \pm 41 \mathrm{~b}, \mathrm{~A}$ & $939 \pm 83 a, A$ & ns & ns & ns \\
\hline \multicolumn{10}{|l|}{ EC-T19 } \\
\hline Unvegetated & $176 \pm 26 a, A$ & $261 \pm 36 a, A$ & $199 \pm 16 a, A$ & $231 \pm 12 \mathrm{c}, \mathrm{A}$ & $389 \pm 17 \mathrm{~b}, \mathrm{~A}$ & $610 \pm 48 \mathrm{a}, \mathrm{A}$ & ns & $*$ & $* * *$ \\
\hline Vegetated & $368 \pm 11 \mathrm{a}, \mathrm{A}$ & $364 \pm 7 a, A$ & $371 \pm 6 a, A$ & $312 \pm 26 b, A$ & $332 \pm 30 \mathrm{ab}, \mathrm{A}$ & $343 \pm 8 \mathrm{a}, \mathrm{A}$ & $* * *$ & $* *$ & $* * *$ \\
\hline \multicolumn{10}{|l|}{$\begin{array}{c}\text { EC-Time } \\
\text { effect }\end{array}$} \\
\hline Unvegetated & ns & ns & ns & ns & ns & ns & & & \\
\hline Vegetated & ** & $* * *$ & * & ns & $*$ & $* *$ & & & \\
\hline
\end{tabular}

SPW pH and EC $\left(\mu \mathrm{S} \cdot \mathrm{cm}^{-1}\right)$ values are means of seven values $( \pm \mathrm{SE})$, the treatment effect in the vegetated and unvegetated conditions (taken separately) is represented by the lower-case letters while the vegetation effect inside a single treatment is represented by the capital letters $(p \leq 0.05)$. The time and level effects for each treatment/(un)vegetated condition are given with level of significance: $\mathrm{ns}=$ non-significant $(p \geq 0.05) ;{ }^{*}(p \leq 0.05) ;{ }^{* *}(p \leq 0.01) ;{ }^{* * *}(p \leq 0.001)$.

At the top, for both vegetated and non-vegetated conditions, only the $\mathrm{AB}+1 / 3 \mathrm{BC}$ treatment increased SPW pH, while at the bottom, both biochar treatments increased it in the non-vegetated and vegetated pots without a difference between the two biochar treatments (Table 2). At this time, the only level effect was observed for the AB vegetated condition, in which $\mathrm{pH}$ was higher at the top than at the bottom of the tube. At T19, the $\mathrm{pH}$ of the $\mathrm{AB}$ treatment at the upper level still had an acid $\mathrm{pH}(\mathrm{pH} 6$ at the top and $\mathrm{pH} 5.8$ at the bottom). For the unvegetated condition, biochar significantly increased the SPW pH at the top level for both amended treatments. At the bottom level, the $\mathrm{AB}+\mathrm{BC}$ treatment led to a higher $\mathrm{pH}$ increase (1.1 units) than the $\mathrm{AB}+1 / 3 \mathrm{BC}$ treatment ( 0.5 units) compared to the control (Table 2). In the presence of alder (vegetated condition), the $\mathrm{pH}$ with respect to the control increased only at the down level of the $\mathrm{AB}+\mathrm{BC}$ treatment. No difference between top level and down level was observed at that time for all tested conditions (Table 2). 
The increase in $\mathrm{pH}$ due to the addition of biochar to the contaminated soil could be associated with its alkalinity ( $\mathrm{pH} \mathrm{8.46),} \mathrm{the} \mathrm{dissolution} \mathrm{of} \mathrm{metal} \mathrm{oxides,} \mathrm{hydroxides}$ and carbonates and the presence of surface functional groups that act as binding sites for $\mathrm{H}^{+}[31,32]$. The alkalinisation effect of biochar could have beneficial outcomes on the acid mine drainage found on the site by reducing its acidity as $\mathrm{pH}$ in biochar amended conditions were around neutrality.

When evaluating the effect of alder on SPW $\mathrm{pH}$, only two significant modifications were observed: SPW pH was decreased by 0.3 and 0.4 units at the top of the tubes of the vegetated condition of $A B+1 / 3 B C$ and $A B+B C$, respectively, at T19 (Table 2). Such a decrease could be due to the presence of the root system at this level [33], which is known to have an acidification effect [34] mediated by organic acid secretion and cation adsorption [14], and whose activity could be emphasized by the presence of biochar.

Finally, it can be seen that, in some conditions, SPW pH evolved with time, but only in the amended conditions: SPW pH decreased at T19 compared to T7 at the top and bottom of the tubes for the $A B+1 / 3 B C$ (vegetated and unvegetated) and $A B+B C$ (vegetated). Similarly, Cornelissen et al. [35] and Juriga and Šimanský [36] demonstrated that the beneficial action of biochar for $\mathrm{pH}$ tended to decrease over time. Such evolution attests to the reaction of the biochar with the soil particles but also the iron sulphate and root activity, which induced biochar oxidation [13,37], and the leaching of the alkaline materials $[35,36]$.

At T7, the SPW EC values of AB treatment were 213 and $453 \mu \mathrm{S} \mathrm{cm}^{-1}$ at the top of the tubes for the vegetated and non-vegetated conditions, respectively, and 333 and $466 \mu S$ $\mathrm{cm}^{-1}$ at the bottom of the tubes, respectively (Table 2). In the unvegetated conditions, no biochar effect was observed, whatever the sample level; while in the vegetated condition, SPW EC was doubled in the AB + BC treatment compared to the control, but only at the bottom of the tube (Table 2). At the time of sampling, no difference in SPW EC was observed between the top and the bottom of the tube.

At T19, SPW EC values were still low on AB and did not evolve at the top of the tubes, in either vegetated or unvegetated tubes (Table 2). However, at the bottom of the tubes, in the unvegetated condition, both biochar treatments increased SPW EC but the treatment $\mathrm{AB}+\mathrm{BC}$ led to a higher increase $\left(610 \mu \mathrm{S} \mathrm{cm}^{-1}\right)$ than $\mathrm{AB}+1 / 3 \mathrm{BC}\left(389 \mu \mathrm{S} \mathrm{cm}{ }^{-1}\right)$ (Table 2). At that time, in the unvegetated condition, SPW EC was higher at the bottom than at the top of the tubes in $A B+1 / 3 B C$ and $A B+B C$, while in the vegetated condition, SPW EC was lower at the bottom of the tubes than at the top. Biochar is known to have excess electrons in the $\pi$ level of aromatic $C$ and many functional groups, such as hydroxyls, carbonyls, carboxyls and phenolic hydroxyl, on its surface that can be dissolved, dissociated or protonated once biochar is added to the soil $[38,39]$, resulting in higher SPW EC values. Furthermore, the increase in $\mathrm{pH}$ that occurred due to the addition of biochar probably increased salt dissolution and nutrient leaching [13]. The higher EC value at the bottom of the tubes, in the unvegetated condition, could be related to the leaching of the dissolved salts with soil watering, while the fact that EC values were higher at the top of the tubes in the vegetated condition could be attributed to the excretion of compounds by the roots, which are more developed at the top of the tubes, and a reduction of salt leaching through the presence of roots.

When assessing the evolution of the SPW EC with time, the unvegetated condition did not show different EC between T7 and T19, whatever the biochar treatment and the level, while in the vegetated condition, SPW EC decreased with time (from T7 to T19) in all cases except the bottom of $\mathrm{AB}$ (Table 2).

\subsection{SPW Metal(Loid)s Concentration}

The As concentration in the non-amended Abbaretz SPW at T7 (Figure 2a) was $0.60 \mathrm{mg} \cdot \mathrm{L}^{-1}$ at the top level and $2.57 \mathrm{mg} \cdot \mathrm{L}^{-1}$ at the bottom level for the non-vegetated condition, while for the vegetated condition, concentrations were $0.38 \mathrm{mg} \cdot \mathrm{L}^{-1}$ and $1.23 \mathrm{mg} \cdot \mathrm{L}^{-1}$, respectively. At that time, there was no effect of the biochar amendment on SPW As concentration at either the top or bottom level in both vegetated and non-vegetated conditions, 
except for the increase in the SPW at the top level in the vegetated $A B+1 / 3 B C$ compared to the vegetated $\mathrm{AB}$. At T7, SPW As concentrations were higher at the bottom of the tubes compared to the top for the three tested conditions: unvegetated $A B$, vegetated $A B$ and vegetated $A B+B C$ (Figure 2a). A previous study showed that biochar did not possess a sorption site for As [40]. Furthermore, biochar was shown to induce As mobilization in the studies of [20] and [41]. Such an effect was related to the increase in soil pH, as observed here, which induces a decrease in the number of positively charged sites, and thus less sorption sites for As [42].

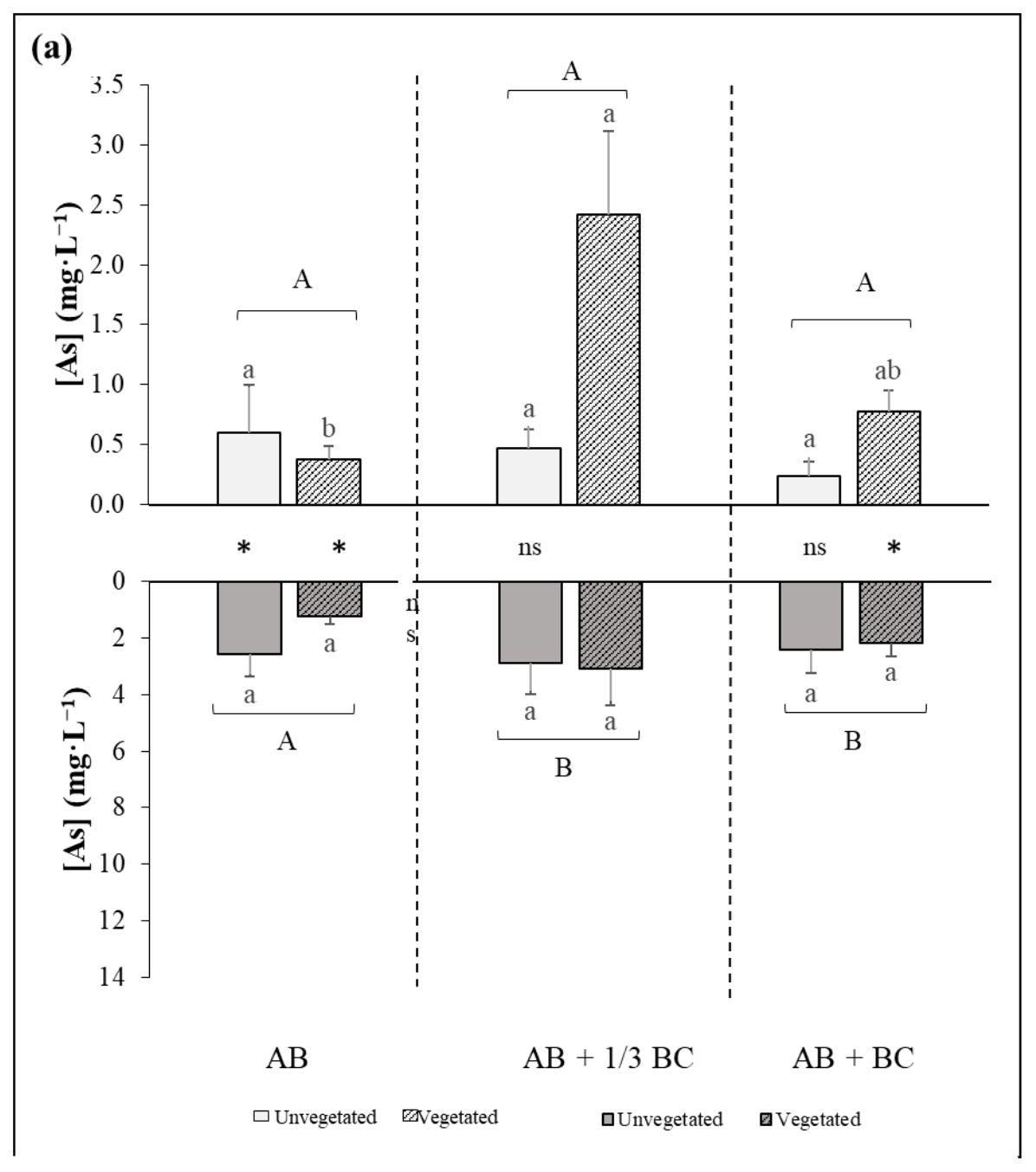

Figure 2. Cont. 


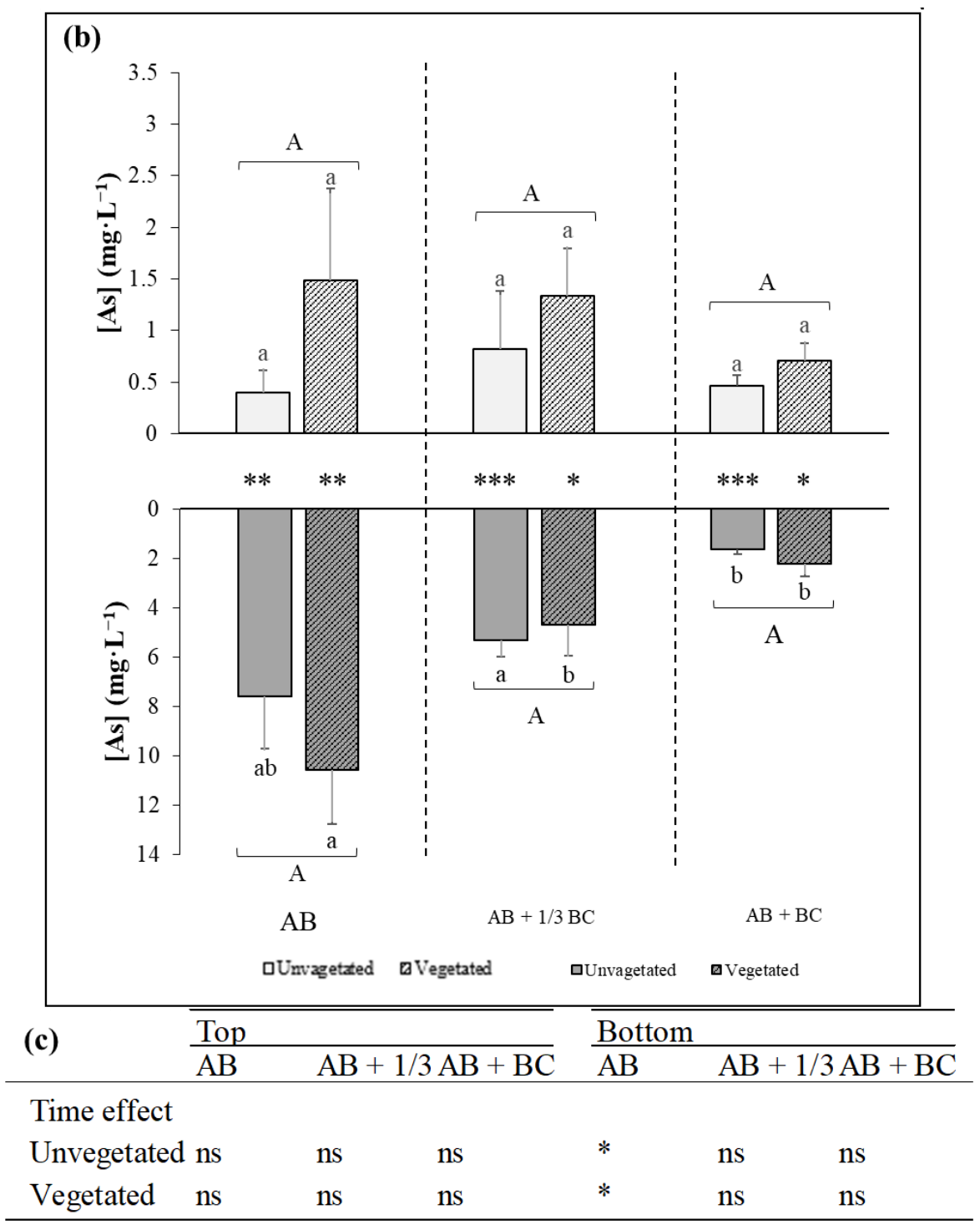

Figure 2. Soil pore water (SPW) arsenic concentration ([As] $=\mathrm{mg} \cdot \mathrm{L}^{-1}$ ) is mean of seven values $( \pm \mathrm{SE})$, determined on Abbaretz $(\mathrm{AB})$ technosol non amended or amended with $2 \%$ biochar added to the top $33 \mathrm{~cm}$ of the tube $(A B+1 / 3 \mathrm{BC})$ or the entirety of the tube $(A B+B C)$ in the unvegetated tubes and in the tubes vegetated with Alnus sp. SPWs were sampled both at the top (light gray box) and at the bottom (gray box) of the tubes in (a) October 2019 (T7) and (b) October 2020 (T19). The treatment effect in the vegetated and unvegetated conditions (taken separately, the level effect for each treatment/(un)vegetated condition and the (c) time effect between T7 and T9 are given with level of significance: $\mathrm{ns}=$ non-significant $(p \geq 0.05) ;{ }^{*}(p \leq 0.05) ;{ }^{* *}(p \leq 0.01) ;{ }^{* * *}(p \leq 0.001)$.

At T19, SPW As concentrations on non-amended AB were: $0.40 \mathrm{mg} \cdot \mathrm{L}^{-1}$ at the top of the non-vegetated tube, $7.58 \mathrm{mg} \cdot \mathrm{L}^{-1}$ at the bottom of the non-vegetated tube, $1.49 \mathrm{mg} \cdot \mathrm{L}^{-1}$ at the top of the vegetated tube, and $10.58 \mathrm{mg} \mathrm{L}^{-1}$ at the bottom of the vegetated tube (Figure $2 b$ ). For the SPW sampled at the top of the tubes, biochar amendment had no effect in either vegetated or non-vegetated conditions. For the bottom sampling, biochar amendment decreased SPW [As]. At that sampling time (T19), in all cases, SPW [As] was higher at the bottom of the tubes compared to the top. This coincided with the SPW $\mathrm{pH}$ increase due to the presence of biochar, which could have induced As mobilization. However, here, an immobilization of As was observed in the biochar amended treatment. This could have been linked to a sorption of As on the iron sulphate, and the sorption of Fe on the biochar surface, creating an indirect As sorption. Indeed, Fresno et al. [43] 
showed that arsenic was associated with a higher proportion of Fe oxides in the treatment involving biochar and Fe. Similarly, Lebrun et al. [40] demonstrated that biochar could be functionalized by fixing Fe onto its surface, which ameliorated its capacity to sorb As in sorption tests. Some studies showed that biochar was capable of sorbing As [32,44], showing inconsistent effects of biochar on As mobility depending on soil type, biochar feedstock and time.

Finally, from the comparison of As concentrations at the top and the bottom of the tubes, results showed that As was highly leached from the top towards the bottom of the tubes in all treatments. This showed that, although biochar was capable of reducing As mobility after 17 months, a high proportion of As still leached from the tubes. Thus, biochar amendment was not able to significantly reduce the risk of As leaching in acid mine drainage.

Since iron sulphate was added to all tubes, Fe concentrations were measured in SPW. At $\mathrm{T} 7$, in the non-vegetated $\mathrm{AB}$, concentration was $0.32 \mathrm{mg} \cdot \mathrm{L}^{-1}$ at the top and $4.27 \mathrm{mg} \cdot \mathrm{L}^{-1}$ at the bottom, while in the vegetated $\mathrm{AB}$ treatments, concentration was $0.07 \mathrm{mg} \cdot \mathrm{L}^{-1}$ and $6.25 \mathrm{mg} \cdot \mathrm{L}^{-1}$, respectively (Figure 3a). At the top of the tubes, there was no effect of biochar amendment on SPW Fe concentration in neither non-vegetated nor vegetated conditions. At the bottom of the tube, the addition of biochar decreased SPW Fe concentration, in the absence and presence of Alnus plants. At that time, SPW Fe concentration was higher at the bottom of the tube compared to the top only in the AB treatment, with and without plants.

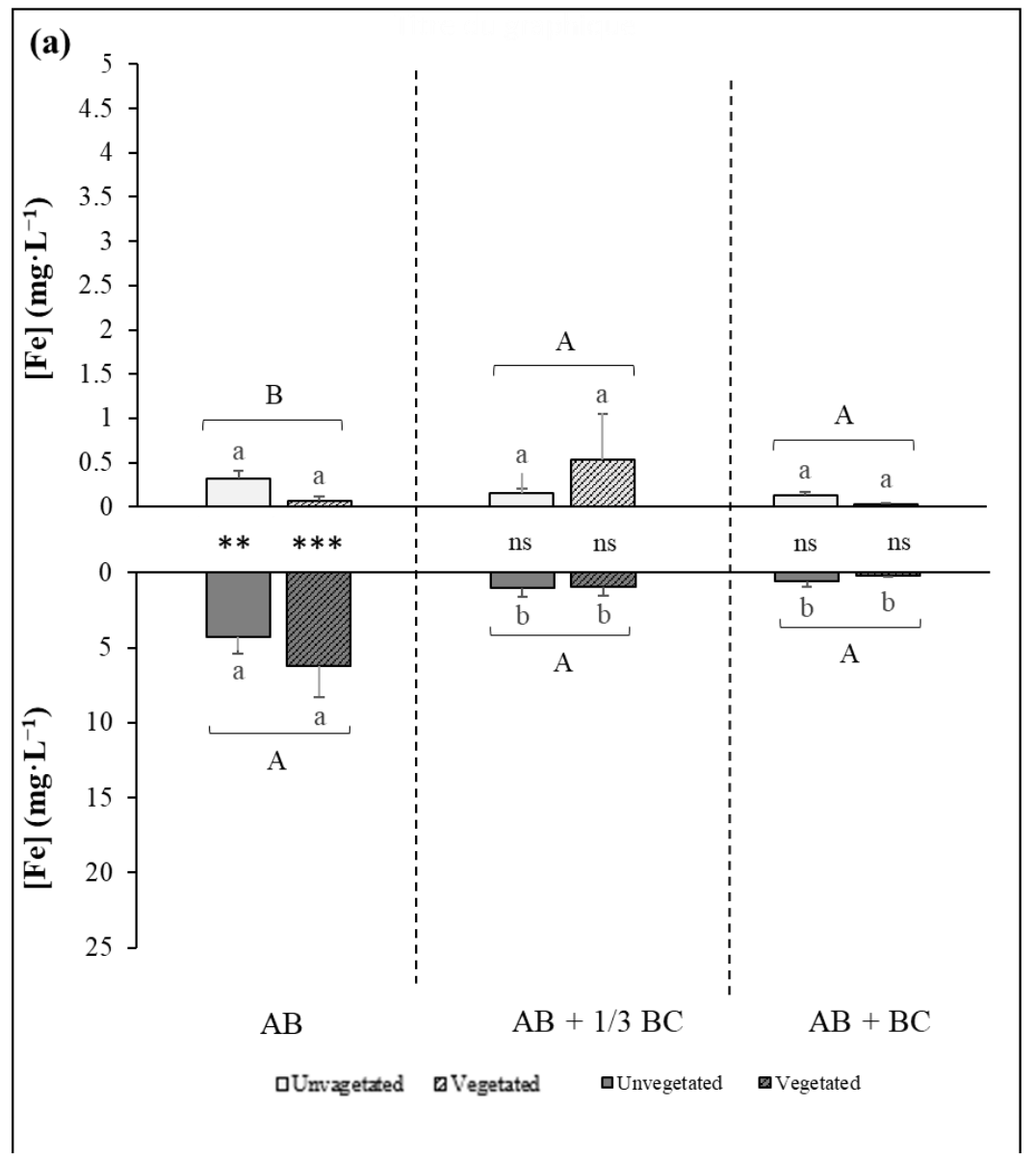

Figure 3. Cont. 


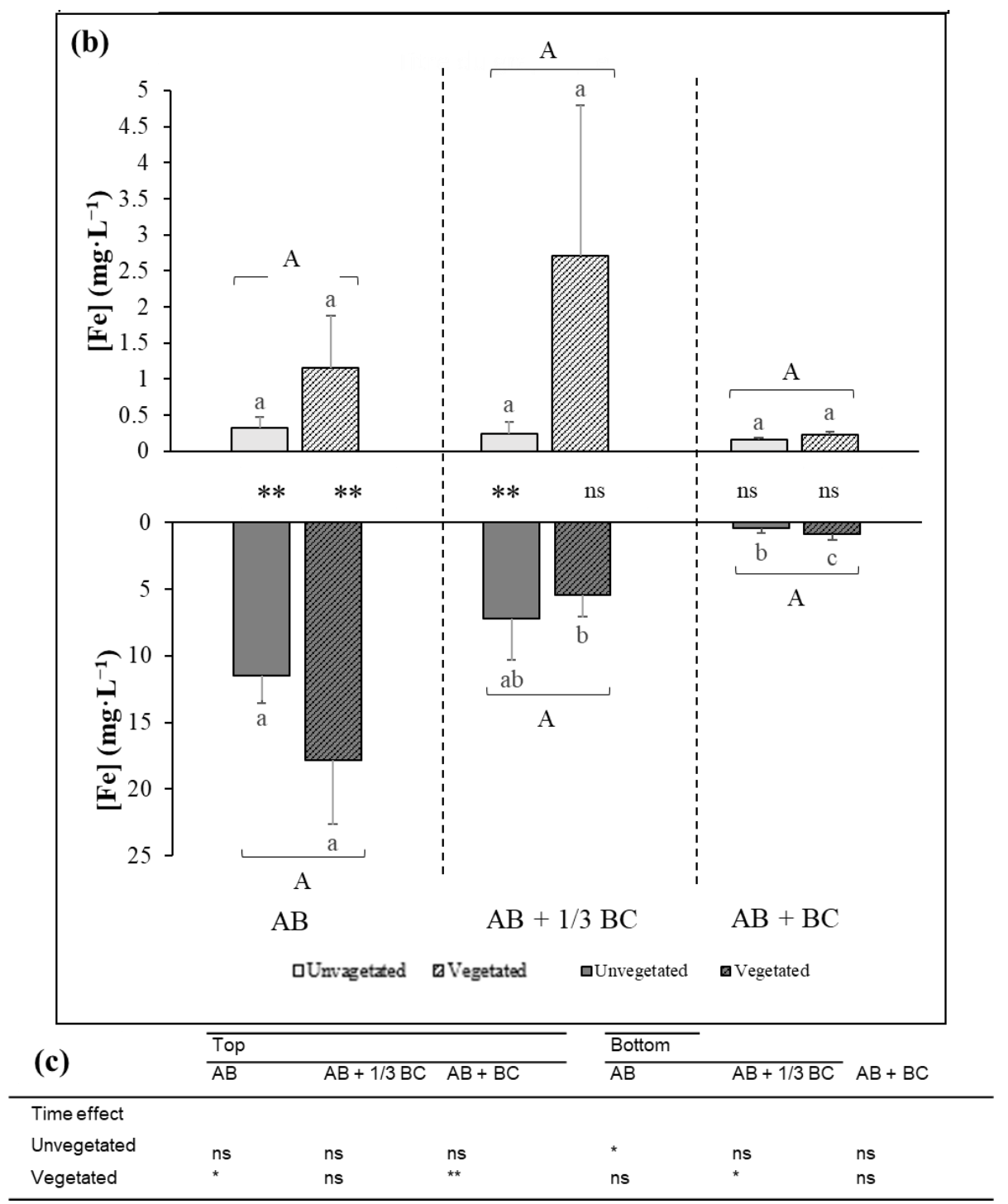

Figure 3. Soil pore water (SPW) iron concentration $\left([\mathrm{Fe}]=\mathrm{mg} \cdot \mathrm{L}^{-1}\right)$ is mean of seven values $( \pm \mathrm{SE})$, determined on Abbaretz $(\mathrm{AB})$ technosol non amended or amended with $2 \%$ biochar added on the top $33 \mathrm{~cm}$ of the tube $(A B+1 / 3 B C)$ or on the tube entirety $(A B+B C)$ in the unvegetated tubes and in the tubes vegetated with Alnus sp. SPWs were sampled both at the top (light gray box) and at the bottom (gray box) of the tubes, in (a) October 2019 (T7) and in (b) October 2020 (T19). The treatment effect in the vegetated and unvegetated conditions (taken separately, the level effect for each treatment/(un)vegetated condition and the (c) time effect between T7 and T9 are given with level of significance: $\mathrm{ns}=$ non-significant $(p \geq 0.05){ }^{*}(p \leq 0.05) ;{ }^{* *}(p \leq 0.01) ;{ }^{* * *}(p \leq 0.001)$.

At $\mathrm{T} 19, \mathrm{AB}$ treatment contained $0.32 \mathrm{mg} \cdot \mathrm{L}^{-1} \mathrm{Fe}$ and $11.49 \mathrm{mg} \cdot \mathrm{L}^{-1} \mathrm{Fe}$ at the top and bottom of the non-vegetated tubes and $1.16 \mathrm{mg} \cdot \mathrm{L}^{-1} \mathrm{Fe}$ and $17.87 \mathrm{mg} \cdot \mathrm{L}^{-1} \mathrm{Fe}$, respectively, for the vegetated condition (Figure 3b). Similarly to T7, the biochar amendment had no effect on SPW Fe concentration measured at the top of the tubes. At the bottom of the tube, in the non-vegetated condition, only $\mathrm{AB}+\mathrm{BC}$ had lower Fe concentration compared to $\mathrm{AB}$, whereas in the vegetated condition, $\mathrm{AB}+\mathrm{BC}$ induced a higher decrease in Fe concentration than $\mathrm{AB}+1 / 3 \mathrm{BC}$, compared to $\mathrm{AB}$. At that time (T19), SPW Fe concentration was higher at the bottom of the tubes than at the top, for the $\mathrm{AB}$ treatment, vegetated and non-vegetated, and $\mathrm{AB}+1 / 3 \mathrm{BC}$ non-vegetated.

The reduction of Fe concentration in SPW with biochar could be related to the capacity of biochar to sorb positively charged cations such as $\mathrm{Fe}$ and the induced $\mathrm{pH}$ increase, as 
demonstrated in the study of Lebrun et al. [13], in which SPW [Fe] was negatively correlated with SPW pH. Moreover, at both times, Fe concentration was higher at the bottom of the tube than at the top, demonstrating the great leaching potential of Fe. However, this was only significant in the non-amended Abbaretz technosol, demonstrating that biochar was capable of reducing the risk of Fe leaching.

The presence of the Alnus plant increased SPW [As] at the top of the tubes for the two biochar amended conditions in T7. However, at T19, there was no effect of Alnus growth on SPW As concentration. Regarding SPW Fe concentration, there was no effect of plant growth, at either sampling times or in any condition.

The mobilization of As in the presence of plants was observed in the study of Lebrun et al. [45] with Salix viminalis and with alder and birch [14]. It may be related to the activity of the roots, as demonstrated in [33] and [46]. This is supported by the fact that As mobilization only happened at the top of the tubes where the root system was the most developed and active. When assessing time effect, the only significant evolution in SPW As concentration was observed at the bottom of the AB treatment, in both vegetated and non-vegetated pots (Figure 2c). Similarly, SPW Fe concentrations were higher at T19 compared to $T 7$ for unvegetated $A B$ (bottom), vegetated $A B$ (up), vegetated $A B+1 / 3 B C$ (down) and vegetated $A B+B C$ (up) (Figure $3 c$ ). These results are consistent with the studies of Lebrun et al. [13], and Lebrun et al. [29] and demonstrate its capacity to immobilize metal(loid) changes with time and biochar oxidation.

\subsection{Stems Dry Weight (DW)}

In the investigated time (T19), no significant difference was detected in the dry weight of the alder stems between the various treatments (Figure 4). Such neutral effect of biochar on stem biomass production was also observed in Lebrun et al. [13] and could be explained by the fact that Alnus plants were capable of growing on the non-amended $A B$ due to their tolerance to metal(loid)s and their capacity to grow on degraded unfertile soils $[47,48]$.

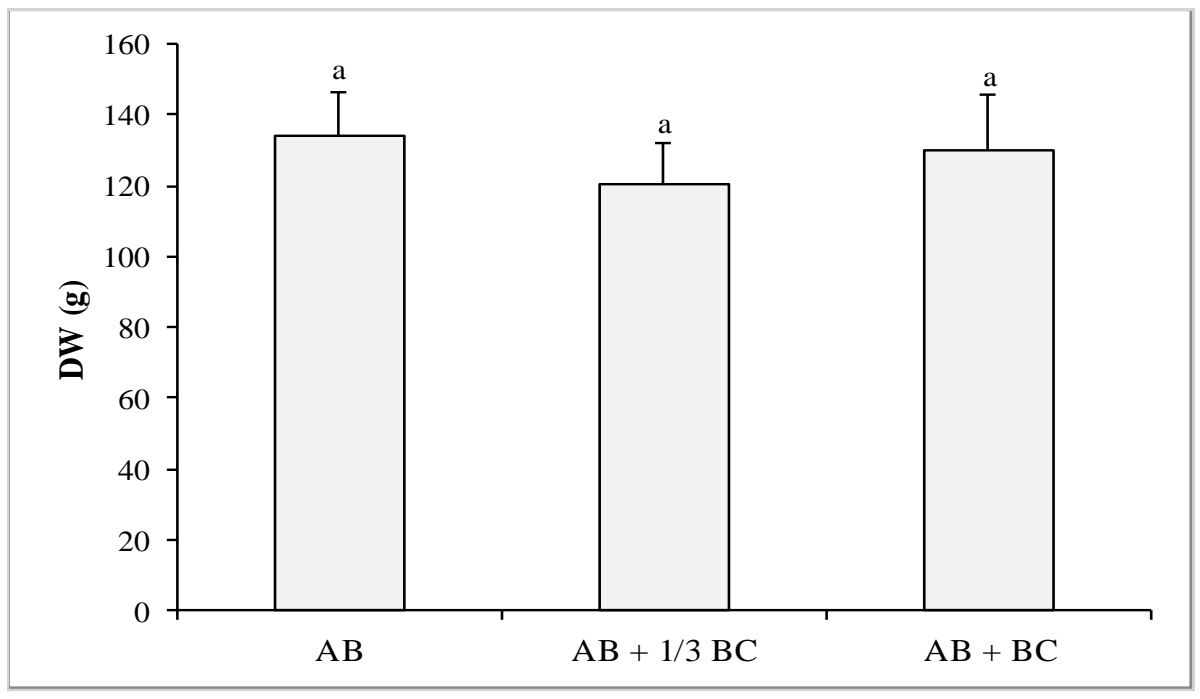

Figure 4. Stems dry weight (DW = g) of the Alnus planted in March 2019 (T0) and sampled in October 2020 (T19), grown on Abbaretz (AB) technosol non amended or amended with $2 \%$ biochar added on the top $33 \mathrm{~cm}$ of the tube $(\mathrm{AB}+1 / 3 \mathrm{BC})$ or on all the tube $(\mathrm{AB}+\mathrm{BC})$. The treatment effect represented by the letters $(p \leq 0.05)$ is mean of seven values $( \pm \mathrm{SE})$.

\subsection{Plant Organs Metal(Loid)s Concentrations}

For the concentration of As and Fe in the plant organs (roots, stems and leaves), no differences were found at T19 among the treatments (Figure 5), similarly to what was observed in [13]. 

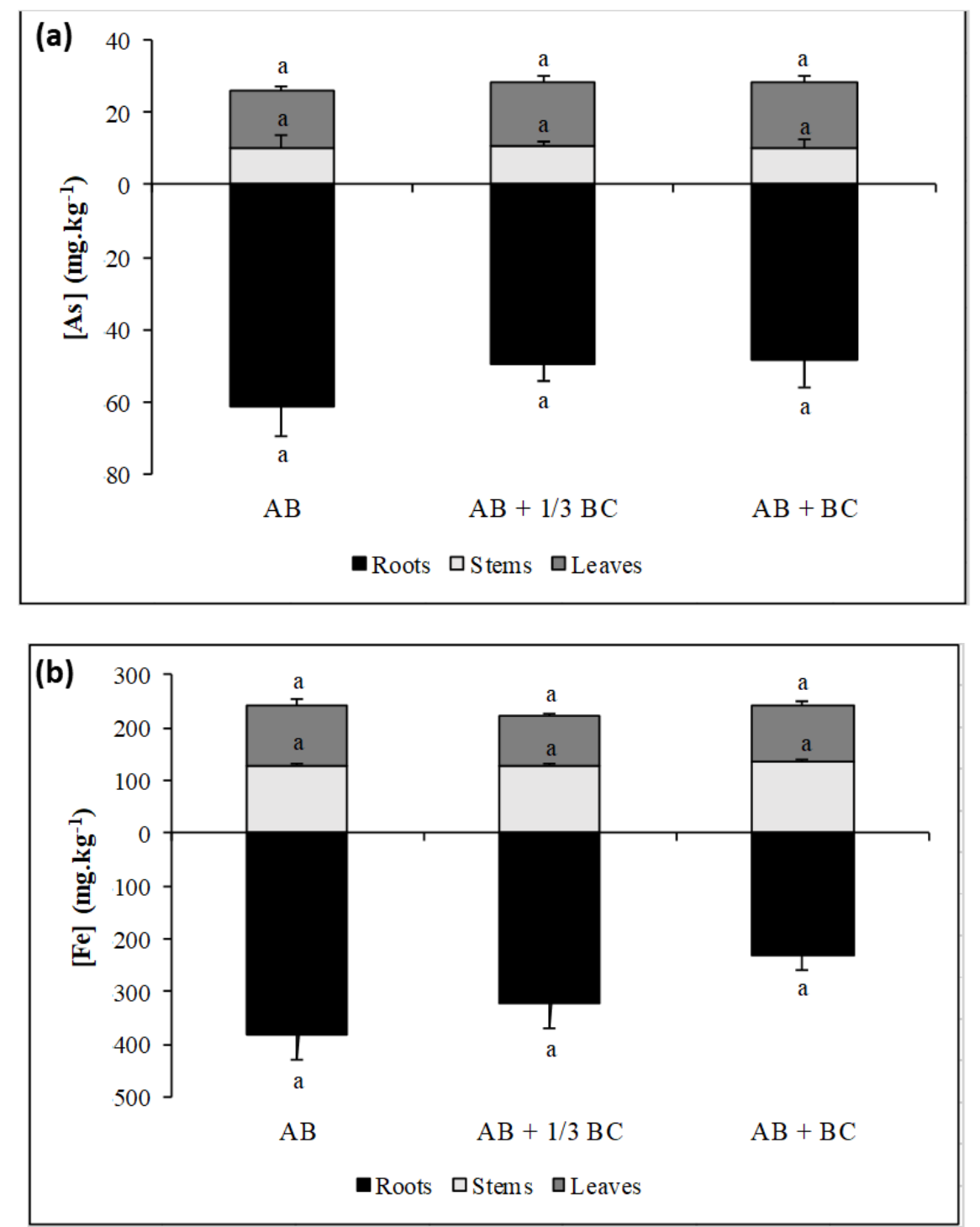

Figure 5. (a) Arsenic ([As] $\left.=\mathrm{mg} \cdot \mathrm{kg}^{-1}\right)$ and (b) iron $\left([\mathrm{Fe}]=\mathrm{mg} \cdot \mathrm{kg}^{-1}\right)$ concentrations in the different organs (gray box, leaves; light gray box, stems; black box, roots) of the Alnus planted in March 2019 (T0) and sampled in October 2020 (T19), grown on Abbaretz (AB) technosol non amended or amended with $2 \%$ biochar added to the top $33 \mathrm{~cm}$ of the tube $(A B+1 / 3 \mathrm{BC})$ or all of the tube $(A B+B C)$. Plant organs were sampled in October 2020. The treatment effect represented by the letters $(p \leq 0.05)$ is mean of seven values $( \pm \mathrm{SE})$.

Such results, however, were unexpected, since biochar tended to decrease SPW As and Fe concentrations in some cases. The decrease in As and Fe mobility was only observed at the bottom of the tubes, while at the top, where roots developed and took up their necessary water and nutrients, biochar had no effect on As and Fe mobility. Furthermore, As and Fe concentrations were only slightly higher in the roots compared to the aerial parts, showing that translocation of As and Fe occurred in Alnus plants, making them not the best choice for phytostabilization process and more particularly within the framework of the installation of processes of phytomanagement where it is preferable to privilege species which limit the translocation of pollutants to the aerial parts, which thus make the produced biomass hardly valorizable without a stage of depollution. 


\section{Conclusions}

This study evaluated the potential of a biochar amendment, associated with iron sulphate, and alder growth for the reduction of As toxicity and environmental risks in a former tin mine. Results showed that biochar amendment was capable of increasing soil $\mathrm{pH}$-an effect that decreased with time. Moreover, a reduction in As mobility was measured, but only after 17 months and at the bottom of the tubes. In most cases, no difference was found among the application methods, demonstrating the potential of biochar surface application in the field. Moreover, alder was able to grow on the contaminated soil, even without biochar, which shows its tolerance towards As and thus its potential as a phytostabilizor plant. However, the study also showed that As and Fe were still highly leached towards the bottom of the tube, although it was reduced by biochar, and that alder growth tended to mobilize metal(loid)s. Therefore, it is important to monitor the biochar-alder association over a longer time period in order to evaluate the possible negative outcomes on metal(loid) leaching and acid mine drainage.

Author Contributions: Conceptualization, D.M. and S.B.; methodology, G.P., M.S., M.L., D.M. and S.B.; software, G.P.; validation, M.L., D.M. and S.B.; writing—original draft preparation, G.P.; writingreview and editing, M.L., D.M. and S.B.; visualization. All authors have read and agreed to the published version of the manuscript.

Funding: This research received no external funding.

Institutional Review Board Statement: Not applicable.

Informed Consent Statement: Not applicable.

Data Availability Statement: Not applicable.

Conflicts of Interest: The authors declare no conflict of interest.

\section{References}

1. European Commission; Joint Research Centre; Institute for Environment and Sustainability. Joint Research Centre. Institute for Environment and Sustainability. Progress in the Management of Contaminated Sites in Europe; Publications Office of the European Union: Luxembourg, 2014; Available online: https:/ / data.europa.eu/doi/10.2788/4658 (accessed on 23 June 2021).

2. Adedeji, O.H.; Olayinka, O.; Tope-Ajayi, O.; Adekoya, A. Assessing spatial distribution, potential ecological and human health risks of soil heavy metals contamination around a Trailer Park in Nigeria. Sci. Afr. 2020, 10, e00650. [CrossRef]

3. Edogbo, B.; Okolocha, E.; Maikai, B.; Aluwong, T.; Uchendu, C. Risk analysis of heavy metal contamination in soil, vegetables and fish around Challawa area in Kano State, Nigeria. Sci. Afr. 2020, 7, e00281. [CrossRef]

4. Gautam, P.K.; Gautam, R.K.; Banerjee, S.; Chattopadhyaya, M.C.; Pandey, J.D. Heavy metals in the environment: Fate, transport, toxicity and remediation technologies. Heavy Met. Environ. 2016, 60, 101-130.

5. Ghosh, D.; Maiti, S.K. Biochar assisted phytoremediation and biomass disposal in heavy metal contaminated mine soils: A review. Int. J. Phytoremediation 2020, 23, 559-576. [CrossRef] [PubMed]

6. Ali, H.; Khan, E.; Sajad, M.A. Phytoremediation of heavy metals-Concepts and applications. Chemosphere 2013, 91, 869-881. [CrossRef]

7. Bakshi, S.; Banik, C.; Rathke, S.J.; Laird, D.A. Arsenic sorption on zero-valent iron-biochar complexes. Water Res. 2018, 137, 153-163. [CrossRef] [PubMed]

8. European Food Safety Authority. Dietary exposure to inorganic arsenic in the European population. EFSA J. 2014, 12. [CrossRef]

9. Hamby, D. Site remediation techniques supporting environmental restoration activities-A review. Sci. Total Environ. 1996, 191, 203-224. [CrossRef]

10. Mulligan, C.; Yong, R.; Gibbs, B. Remediation technologies for metal-contaminated soils and groundwater: An evaluation. Eng. Geol. 2001, 60, 193-207. [CrossRef]

11. Shao, Y.; Yan, T.; Wang, K.; Huang, S.; Yuan, W.; Qin, F.G. Soil heavy metal lead pollution and its stabilization remediation technology. Energy Rep. 2020, 6, 122-127. [CrossRef]

12. Zine, H.; Midhat, L.; Hakkou, R.; El Adnani, M.; Ouhammou, A. Guidelines for a phytomanagement plan by the phytostabilization of mining wastes. Sci. Afr. 2020, 10, e00654. [CrossRef]

13. Lebrun, M.; Miard, F.; Nandillon, R.; Scippa, G.S.; Bourgerie, S.; Morabito, D. Biochar effect associated with compost and iron to promote $\mathrm{Pb}$ and As soil stabilization and Salix viminalis L. growth. Chemosphere 2019, 222, 810-822. [CrossRef]

14. Lebrun, M.; Nandillon, R.; Miard, F.; Scippa, G.S.; Bourgerie, S.; Morabito, D. Application of amendments for the phytoremediation of a former mine technosol by endemic pioneer species: Alder and birch seedlings. Environ. Geochem. Health 2021, 43, 77-89. [CrossRef] 
15. Nandillon, R.; Lebrun, M.; Miard, F.; Gaillard, M.; Sabatier, S.; Villar, M.; Bourgerie, S.; Morabito, D. Capability of amendments (biochar, compost and garden soil) added to a mining technosol contaminated by $\mathrm{Pb}$ and As to allow poplar seed (Populus nigra L.) germination. Environ. Monit. Assess. 2019, 191, 465. [CrossRef]

16. Nagula, S.; Ramanjaneyulu, A.V. Biochar-The New Black Gold. Biot. Res. Today 2020, 2, 425-427.

17. Mary, G.S.; Sugumaran, P.; Niveditha, S.; Ramalakshmi, B.; Ravichandran, P.; Seshadri, S. Production, characterization and evaluation of biochar from pod (Pisum sativum), leaf (Brassica oleracea) and peel (Citrus sinensis) wastes. Int. J. Recycl. Org. Waste Agric. 2016, 5, 43-53. [CrossRef]

18. Yan, C.; Wen, J.; Wang, Q.; Xing, L.; Hu, X. Mobilization or immobilization? The effect of HDTMA-modified biochar on as mobility and bioavailability in soil. Ecotoxicol. Environ. Saf. 2021, 207, 111565. [CrossRef]

19. Duan, X.; Zhang, C.; Srinivasakannan, C.; Wang, X. Waste walnut shell valorization to iron loaded biochar and its application to arsenic removal. Resour. Technol. 2017, 3, 29-36. [CrossRef]

20. Simiele, M.; Lebrun, M.; Miard, F.; Trupiano, D.; Poupart, P.; Forestier, O.; Scippa, G.S.; Bourgerie, S.; Morabito, D. Assisted phytoremediation of a former mine soil using biochar and iron sulphate: Effects on As soil immobilization and accumulation in three Salicaceae species. Sci. Total Environ. 2020, 710, 136203. [CrossRef]

21. Mahmood-Ul-Hassan, M.; Yousra, M.; Ahmad, R.; Sarwar, S. Arsenic Contamination in Rice Grown Under Anaerobic Condition in Arid Agriculture: Assessment and Remediation. Bull. Environ. Contam. Toxicol. 2019, 103, 865-870. [CrossRef]

22. Xu, X.; Chen, C.; Wang, P.; Kretzschmar, R.; Zhao, F.-J. Control of arsenic mobilization in paddy soils by manganese and iron oxides. Environ. Pollut. 2017, 231, 37-47. [CrossRef] [PubMed]

23. Irshad, M.K.; Noman, A.; Alhaithloul, H.A.; Adeel, M.; Rui, Y.; Shah, T.; Zhu, S.; Shang, J. Goethite-modified biochar ameliorates the growth of rice (Oryza sativa L.) plants by suppressing Cd and As-induced oxidative stress in Cd and As co-contaminated paddy soil. Sci. Total Environ. 2020, 717, 137086. [CrossRef]

24. Islam, S.; Chen, Y.; Weng, L.; Ma, J.; Khan, Z.H.; Liao, Z.; Magid, A.S.I.A.; Li, Y. Watering techniques and zero-valent iron biochar $\mathrm{pH}$ effects on As and Cd concentrations in rice rhizosphere soils, tissues and yield. J. Environ. Sci. 2021, 100, 144-157. [CrossRef] [PubMed]

25. Lin, L.; Gao, M.; Qiu, W.; Wang, D.; Huang, Q.; Song, Z. Reduced arsenic accumulation in indica rice (Oryza sativa L.) cultivar with ferromanganese oxide impregnated biochar composites amendments. Environ. Pollut. 2017, 231, 479-486. [CrossRef]

26. Kumpiene, J.; Lagerkvist, A.; Maurice, C. Stabilization of $\mathrm{As}, \mathrm{Cr}, \mathrm{Cu}, \mathrm{Pb}$ and $\mathrm{Zn}$ in soil using amendments-A review. Waste Manag. 2008, 28, 215-225. [CrossRef]

27. Escobar, M.P.; Dussán, J. Phytoremediation potential of chromium and lead byAlnus acuminatasubsp.acuminata. Environ. Prog. Sustain. Energy 2016, 35, 942-948. [CrossRef]

28. Lebrun, M.; Miard, F.; Bucci, A.; Trupiano, D.; Nandillon, R.; Naclerio, G.; Scippa, G.S.; Morabito, D.; Bourgerie, S. Evaluation of direct and biochar carrier-based inoculation of Bacillus sp. on As- and Pb-contaminated technosol: Effect on metal(loid) availability, Salix viminalis growth, and soil microbial diversity/activity. Environ. Sci. Pollut. Res. 2021, 28, 11195-11204. [CrossRef] [PubMed]

29. Lebrun, M.; Miard, F.; Nandillon, R.; Hattab-Hambli, N.; Scippa, G.S.; Bourgerie, S.; Morabito, D. Eco-restoration of a mine technosol according to biochar particle size and dose application: Study of soil physico-chemical properties and phytostabilization capacities of Salix viminalis. J. Soils Sediments 2018, 18, 2188-2202. [CrossRef]

30. R. Team C. R language Definition; R Foundation for Statistical Computing: Vienna, Austria, 2000.

31. Dai, Z.; Wang, Y.; Muhammad, N.; Yu, X.; Xiao, K.; Meng, J.; Liu, X.; Xu, J.; Brookes, P.C. The Effects and Mechanisms of Soil Acidity Changes, following Incorporation of Biochars in Three Soils Differing in Initial pH. Soil Sci. Soc. Am. J. 2014, 78, 1606-1614. [CrossRef]

32. Lebrun, M.; Van Poucke, R.; Miard, F.; Scippa, G.S.; Bourgerie, S.; Morabito, D.; Tack, F.M.G. Effects of carbon-based materials and redmuds on metal(loid) immobilization and growth of Salix dasyclados Wimm. on a former mine Technosol contaminated by arsenic and lead. Land Degrad. Dev. 2021, 32, 467-481. [CrossRef]

33. Kidd, P.; Barceló, J.; Bernal, M.P.; Navari-Izzo, F.; Poschenrieder, C.; Shilev, S.; Clemente, R.; Monterroso, C. Trace element behaviour at the root-soil interface: Implications in phytoremediation. Environ. Exp. Bot. 2009, 67, 243-259. [CrossRef]

34. Podwika, M.; Solek-Podwika, K.; Ciarkowska, K. Changes in the properties of grassland soils as a result of afforestation. iForest-Biogeosciences For. 2018, 11, 600-608. [CrossRef]

35. Cornelissen, G.; Jubaedah; Nurida, N.L.; Hale, S.E.; Martinsen, V.; Silvani, L.; Mulder, J. Fading positive effect of biochar on crop yield and soil acidity during five growth seasons in an Indonesian Ultisol. Sci. Total Environ. 2018, 634, 561-568. [CrossRef]

36. Juriga, M.; Šimanský, V. Effects of Biochar and its Reapplication on Soil pH and Sorption Properties of Silt Loam Haplic Luvisol. Acta Hortic. et Regiotect. 2019, 22, 65-70. [CrossRef]

37. Miretzky, P.; Cirelli, A.F. Remediation of Arsenic-Contaminated Soils by Iron Amendments: A Review. Crit. Rev. Environ. Sci. Technol. 2010, 40, 93-115. [CrossRef]

38. Guo, M.; Song, W.; Tian, J. Biochar-Facilitated Soil Remediation: Mechanisms and Efficacy Variations. Front. Environ. Sci. 2020, 8, 521512. [CrossRef]

39. Senthilkumar, R.; Prasad, D.M.R. Sorption of Heavy Metals onto Biochar. In Applications of Biochar for Environmental Safety; Abdelhafez, A.A., Abbas, M.H.H., Eds.; InTechOpen: London, UK, 2020. [CrossRef] 
40. Lebrun, M.; Miard, F.; Renouard, S.; Nandillon, R.; Scippa, G.S.; Morabito, D.; Bourgerie, S. Effect of Fe-functionalized biochar on toxicity of a technosol contaminated by $\mathrm{Pb}$ and As: Sorption and phytotoxicity tests. Environ. Sci. Pollut. Res. 2018, 25, 33678-33690. [CrossRef] [PubMed]

41. Beesley, L.; Moreno-Jiménez, E.; Gomez-Eyles, J.L. Effects of biochar and greenwaste compost amendments on mobility, bioavailability and toxicity of inorganic and organic contaminants in a multi-element polluted soil. Environ. Pollut. 2010, 158, 2282-2287. [CrossRef]

42. Lomaglio, T.; Hattab-Hambli, N.; Bret, A.; Miard, F.; Trupiano, D.; Scippa, G.S.; Motelica-Heino, M.; Bourgerie, S.; Morabito, $\mathrm{D}$. Effect of biochar amendments on the mobility and (bio) availability of $\mathrm{As}, \mathrm{Sb}$ and $\mathrm{Pb}$ in a contaminated mine technosol. $J$. Geochem. Explor. 2017, 182, 138-148. [CrossRef]

43. Fresno, T.; Moreno-Jiménez, E.; Peñalosa, J.M. Assessing the combination of iron sulfate and organic materials as amendment for an arsenic and copper contaminated soil. A chemical and ecotoxicological approach. Chemosphere 2016, 165, 539-546. [CrossRef]

44. Niazi, N.K.; Bibi, I.; Shahid, M.; Ok, Y.S.; Burton, E.; Wang, H.; Shaheen, S.; Rinklebe, J.; Lüttge, A. Arsenic removal by perilla leaf biochar in aqueous solutions and groundwater: An integrated spectroscopic and microscopic examination. Environ. Pollut. 2018, 232, 31-41. [CrossRef] [PubMed]

45. Lebrun, M.; Miard, F.; Nandillon, R.; Léger, J.-C.; Hattab-Hambli, N.; Scippa, G.S.; Bourgerie, S.; Morabito, D. Assisted phytostabilization of a multicontaminated mine technosol using biochar amendment: Early stage evaluation of biochar feedstock and particle size effects on $\mathrm{As}$ and $\mathrm{Pb}$ accumulation of two Salicaceae species (Salix viminalis and Populus euramericana). Chemosphere 2018, 194, 316-326. [CrossRef] [PubMed]

46. Dong, J.; Mao, W.; Zhang, G.; Wu, F.; Cai, Y. Root excretion and plant tolerance to cadmium toxicity-A review. Plant Soil Environ. 2008, 53, 193-200. [CrossRef]

47. Bélanger, P.-A.; Bellenger, J.-P.; Roy, S. Heavy metal stress in alders: Tolerance and vulnerability of the actinorhizal symbiosis. Chemosphere 2015, 138, 300-308. [CrossRef] [PubMed]

48. Lorenc-Plucińska, G.; Walentynowicz, M.; Niewiadomska, A. Capabilities of alders (Alnus incana and A. glutinosa) to grow in metal-contaminated soil. Ecol. Eng. 2013, 58, 214-227. [CrossRef] 